\title{
Induction of systemic resistance (ISR) against sheath blight of rice caused by Rhizoctonia solani Kuhn using biological seed treatment with Trichoderma
}

\author{
K. K. Sharma \\ Regional Research Station (PAU), Ballowal Saunkhari, Balachaur, S.B.S. Nagar -144521(Punjab), INDIA \\ E-mail:kksharma@pau.edu \\ Received: December 21, 2016; Revised received: April 13, 2017; Accepted: August 27, 2017
}

\begin{abstract}
Sheath blight caused by Rhizoctonia solani Kuhn has recently noticed one of the most important diseases of rice on almost all the high yielding varieties in major rice growing area. In our study morphologically and molecularly characterized thirty rhizospheric isolates of Trichoderma ( $T$. harzianum and $T$. virens) from different locations of Uttarakhand were evaluated for their mycoparasitic ability, disease (sheath blight) suppressing potential and inducing systemic resistance against Rhizoctonia solani. Maximum inhibition in hyphal growth (58.9 \%) against $R$. solani was recorded with isolate PB 2 followed by PB $3(53.4 \%)$ in confrontation assay. Under glass house condition, minimum disease severity $(13.6 \%)$ was recorded in the treatment where seeds were treated with PB 22 and this treatment also exhibited highest total phenol content $(394 \mu \mathrm{l} / \mathrm{g}) 168$ hours after pathogen inoculation. Total phenol content was also increased maximally $(466 \mu \mathrm{l} / \mathrm{g})$ before pathogen inoculation in the treatment where seeds were treated with PB 22. Moreover, high quality ISR activity was recorded with isolates PB 21, 3, 1, 4, 23, 2 and 16 as they reduced more than 34 percent disease and total phenol contents $456 \mu \mathrm{l} / \mathrm{g}, 449 \mu \mathrm{l} / \mathrm{g}, 442 \mu \mathrm{l} / \mathrm{g}, 440 \mu \mathrm{l} / \mathrm{g}$ and $440 \mu \mathrm{l} / \mathrm{g}, 438 \mu \mathrm{l} / \mathrm{g}$ and $431 \mu \mathrm{l} / \mathrm{g}$ were recorded for respective isolates indicated induction of resistance in paddy against sheath blight disease caused by $R$. solani.
\end{abstract}

Keywords: ISR, Mycoparasitism, Rice, Sheath blight, Total phenol content, Trichoderma

\section{INTRODUCTION}

Sheath blight disease caused by the fungus Rhizoctonia solani Kuhn is a very destructive disease of all the major high yielding rice varieties under favourable weather conditions causing substantial yield loss (Pal et al., 2015). Trichoderma is gaining worldwide importance and acceptance, because of its adaptability and variety of mechanisms involved in disease control (VanWees et al., 2008, Vinale et al., 2014). The capability of Trichoderma sp. to antagonize pathogenic microorganisms is fairly well known and understood globally, however we are not able enough to unveil many questions about the process of systemic resistance induced in plants by these fungi till date (Kotasthane et al., 2015). Induced systemic resistance is believed to be one of the most important mechanisms of biocontrol effects of Trichoderma (Harman, 2006, Segarra, et al., 2009). In one of the first comprehensive studies on induction of resistance in cucumber plants by $T$. harzianum demonstrated by Yedidia et al. (1999). ISR activity in paddy using Aspergillus niger was demonstrated by Sen (2000) when plants raised from strain AN-27 treated seeds exhibited 30 per cent less sheath blight disease as compared to control. Hanson (2000) studied the ability to induce resistance in cotton plants against Verticillium wilt when seeds were treated with dried preparations of two strains of $T$. virens and observed significant reduction in disease severity with both the strains. Keeping this in view, present study was undertaken to find out potential indigenous isolates of the Trichoderma from different locations of Uttarakhand which can either suppress the pathogen i.e. $R$. solani or the sheath blight disease, in order to find biocontrol isolates for application in the field. To fulfill this objective all rhizospheric isolates of Trichoderma were screened in confrontation assay followed by pot experiment under glass house condition and estimation of total phenol content for testing their ability to inhibit the growth of $R$. solani or induce systemic resistance against sheath blight of rice.

\section{MATERIALS AND METHODS}

Experimental materials: Trichoderma strains were isolated from rhizospheric soils of different crops and locations of Uttarakhand (Table 1) and seeds of paddy (cv. Pant Dhan-4) were obtained from SPC, Pantnagar. The tested phytopathogen used in the present study was isolated from agricultural field of district Udham Singh Nagar (Uttarakhand).

Confrontation assay: All the 30 Trichoderma isolates were evaluated for their mycoparastic ability against Rhizoctonia solani following dual culture technique (Dennis and Webster, 1971) on poured PDA medium plates. The Petri dishes were incubated at $25 \pm$ $2^{0} \mathrm{C}$. Per cent reduction in hyphal growth of pathogen 


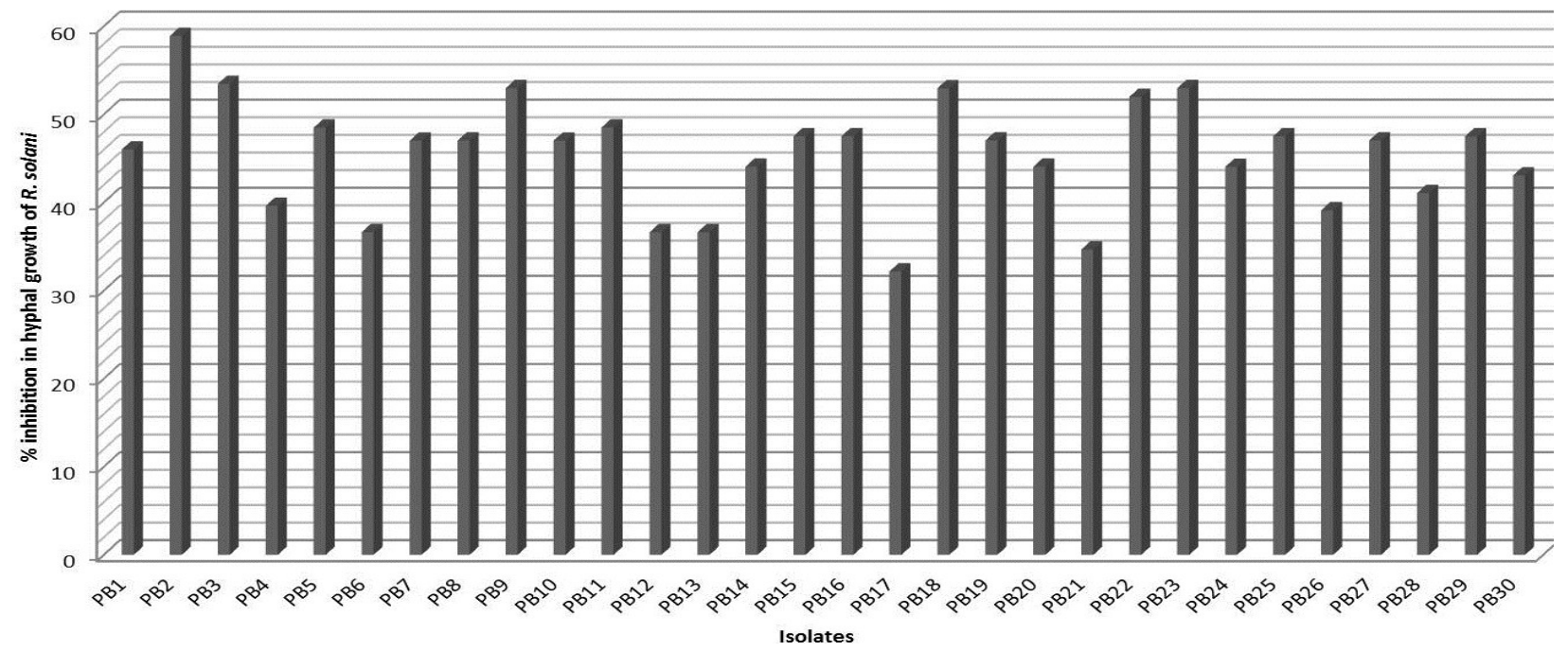

Fig. 1. Percent reduction in hyphal growth of Rhizoctonia solani.

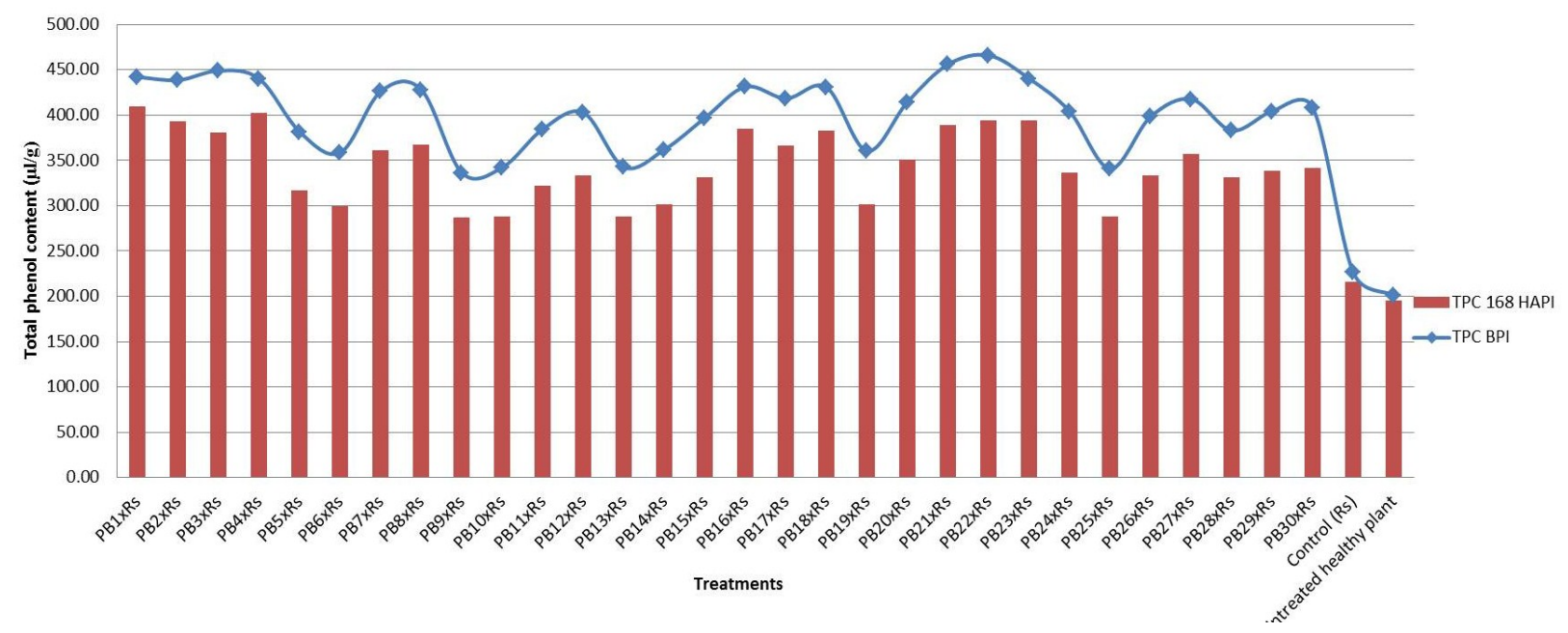

Fig. 2. Total phenol content in rice leaf before pathogen inoculation and 168 hours after pathogen inoculation.

was calculated by using following formula:

$\mathrm{I}=$ (C-T) / C X 100

..Eq 1

$\mathrm{I}=$ Per cent inhibition in mycelial growth, $\mathrm{C}=$ Growth of pathogen in control plate, $\mathrm{T}=$ Growth of pathogen in dual culture plate

Pot experiments: All isolates of Trichoderma were then tested for their pathogen and/or disease suppression ability against sheath blight (Rhizoctonia solani) of rice via pot experiment under glass house conditions and potential isolates were identified for Induction of systemic resistance. Paddy seeds (surface sterilized) were treated with powdered formations of biocontrol agents (@10g/kg seeds; cfu=10 $0^{9} / \mathrm{g}$ powder) and ten seeds per pot were sown with triplicates in plastic pots (5kg capacity) containing sterilized soil. Five days after germination pots were thinned to three plants per pot and watered regularly to keep the proper soil moisture. After 30 days of sowing, second leaf sheaths (from the top) of paddy seedling were inoculated with 3 day-old immature sclerotia of $R$. solani by following the method described by Singh et al. (2000). Observation was recorded on lesion length development after 7 th day of inoculation and percent disease severity and percent reduction in disease severity were calculated by using following formulae:

Percent Disease Severity $($ PDS) $=$ Lesion length / Plant height X 100 ..Eq 2

Extraction of phenols: Phenols were estimated by the procedure described by Sadasivam and Manickam (1997). One gram of leaf tissue was grinded in $5 \mathrm{ml}$ $80 \%$ methanol. The extract was agitated at $70^{\circ} \mathrm{C}$ for 15 minutes. Afterwards in $1 \mathrm{ml}$ sample of methanolic extract, $5 \mathrm{ml}$ distilled water was added to make the final volume $6 \mathrm{ml}$. To this $250 \mu \mathrm{l}$ Folin's reagent was added and the mixture was incubated for $3 \mathrm{~min}$ at room tem-

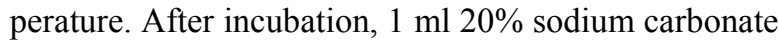
and $1 \mathrm{ml}$ distilled water were added and the solution was incubated for $1 \mathrm{hr}$. at room temperature. Absorbance was recorded at $725 \mathrm{~nm}$. The amount of total phenols was estimated from the standard curve for tannic 
Table 1. Soil samples collected from different locations.

\begin{tabular}{|c|c|c|c|}
\hline Sl. No. & Crop & Location & Isolate code \\
\hline 1 & Paddy & Kathgodam-Haldwani & PB1 \\
\hline 2 & Paddy & Halduchaur-Haldwani & PB2 \\
\hline 3 & Paddy & Lamachaur-Haldwani & PB3 \\
\hline 4 & Paddy & Kherna-Almora & PB4 \\
\hline 5 & Paddy & Kherna-Almora & PB5 \\
\hline 6 & Paddy & Kherna-Almora & PB6 \\
\hline 7 & Paddy & Kherna-Almora & PB7 \\
\hline 8 & Paddy & SPC-Pantnagar & PB8 \\
\hline 9 & Paddy & SPC-Pantnagar & PB9 \\
\hline 10 & Paddy & Rudrapur-U.S. Nagar & PB10 \\
\hline 11 & Paddy & Rudrapur-U.S. Nagar & PB11 \\
\hline 12 & Paddy & Rudrapur-U.S. Nagar & PB12 \\
\hline 13 & Paddy & Rudrapur-U.S. Nagar & PB13 \\
\hline 14 & Paddy & Rudrapur-U.S. Nagar & PB14 \\
\hline 15 & Apple & Mukteshwar-Almora & PB15 \\
\hline 16 & Broccoli & Mukteshwar-Almora & PB16 \\
\hline 17 & Pea & Mukteshwar-Almora & PB17 \\
\hline 18 & Pea & Mukteshwar-Almora & PB18 \\
\hline 19 & Strawberry & Mukteshwar-Almora & PB19 \\
\hline 20 & Walnut & Mukteshwar-Almora & PB20 \\
\hline 21 & Paddy & Premnagar-Dehradun & PB21 \\
\hline 22 & Mustard & Premnagar-Dehradun & PB22 \\
\hline 23 & Maize & Dhalwala-Rishikesh & PB23 \\
\hline 24 & Maize & Bhaniawala-Dehradun & PB24 \\
\hline 25 & Paddy & Bhaniawala-Dehradun & PB25 \\
\hline 26 & Paddy & Mazra-Ranipokhri & PB26 \\
\hline 27 & Maize & Geetanagar Rishikesh & PB27 \\
\hline 28 & Paddy & Raipur-Dehradun & PB28 \\
\hline 29 & Paddy & Raiwala-Haridwar & PB29 \\
\hline 30 & Paddy & Nagani, Tehri Garhwal & PB30 \\
\hline
\end{tabular}

acid and expressed as $\mu \mathrm{g}$ phenol g-1 fresh leaf weight. Data was recorded as total phenolic content in rice leaves, before pathogen inoculation (BPI) and 168 hours after pathogen inoculation (HAPI).

\section{RESULTS}

Results of the mycoparasitism of Trichoderma against Rhizoctonia solani are summarized in figure 1. All thirty isolates were effectively suppressed the hyphal growth of $R$. solani in-vitro which was ranged from $37.2 \%$ to $58.9 \%$. Maximum reduction in hyphal growth was recorded with isolate PB 2 (58.9\%) followed by PB3 (53.4\%) while isolate PB 17 resulted in minimum reduction of hyphal growth. Only six isolates viz. PB 2, 3, 9, 18, 22 and 23 inhibited more than 50 percent hyphal growth of the pathogen in-vitro. Isolates PB 3, 9, 18 and 23; PB 5 and 11; PB 15, 16 and 25; PB 8, 10, 19, 27 and 29; PB 14, 20 and 24; PB 4 and 26; PB6, 12 and 13 were at par. Furthermore, all the Trichoderma isolates were evaluated through seed treatment under glass house pot experiments for their disease suppression potential to induce systemic resistance (ISR) in paddy against sheath blight fungus and results are summarized in table 2 . Results revealed that all the isolates significantly suppressed sheath
Table 2. ISR activity of Trichoderma isolates against sheath blight of paddy.

\begin{tabular}{|c|c|c|c|c|}
\hline $\begin{array}{l}\text { Isolate } \\
\text { Code }\end{array}$ & $\begin{array}{l}\text { Lesion } \\
\text { length } \\
(\mathrm{mm})\end{array}$ & $\begin{array}{l}\text { Lesion } \\
\text { width } \\
\text { (mm) }\end{array}$ & $\begin{array}{l}\text { \% Disease } \\
\text { Severity }^{*}\end{array}$ & $\begin{array}{lr}\% & \text { reduction } \\
\text { in } & \text { Disease } \\
\text { Severity }^{*}\end{array}$ \\
\hline $\mathrm{PB} 1 \times R s$ & 21.7 & 2.7 & $19.1(25.9)$ & $38.5(38.3)$ \\
\hline $\mathrm{PB} 2 \times R s$ & 11.3 & 3.7 & $17.7(24.9)$ & $37.0(37.5)$ \\
\hline $\mathrm{PB} 3 \times R s$ & 7.7 & 3.3 & $16.0(23.6)$ & $42.5(40.7)$ \\
\hline $\mathrm{PB} 4 \mathrm{x} R s$ & 12.7 & 2.0 & $20.7(27.0)$ & 37.7 (37.9) \\
\hline $\mathrm{PB} 5 \mathrm{x} R s$ & 5.3 & 4.0 & $25.4(30.2)$ & $17.3(24.5)$ \\
\hline $\mathrm{PB} 6 \mathrm{x} R s$ & 15.3 & 2.7 & $27.4(31.6)$ & $9.6(18.0)$ \\
\hline $\mathrm{PB} 7 \mathrm{x} R s$ & 13.7 & 3.7 & $19.5(26.2)$ & $29.4(32.9)$ \\
\hline $\mathrm{PB} 8 \mathrm{x} R s$ & 7.7 & 3.0 & $19.2(26.0)$ & $29.7(33.0)$ \\
\hline $\mathrm{PB} 9 \times R s$ & 12.3 & 3.7 & $26.6(31.0)$ & 5.9 (13.9) \\
\hline $\mathrm{PB} 10 \mathrm{x} R s$ & 15.3 & 5.7 & $25.6(30.4)$ & $6.0(13.8)$ \\
\hline $\mathrm{PB} 11 \mathrm{x} R s$ & 22.3 & 4.7 & $26.8(31.2)$ & $18.4(25.4)$ \\
\hline $\mathrm{PB} 12 \mathrm{x} R s$ & 20.7 & 5.3 & $23.9(29.2)$ & $22.3(28.1)$ \\
\hline $\mathrm{PB} 13 \times R s$ & 27.0 & 6.0 & $25.7(30.5)$ & $6.0 \quad(13.8)$ \\
\hline $\mathrm{PB} 14 \mathrm{x} R s$ & 12.7 & 4.7 & $21.7(27.8)$ & $10.0(18.3)$ \\
\hline $\mathrm{PB} 15 \mathrm{x} R s$ & 20.0 & 4.3 & $20.4(26.9)$ & $21.2(27.4)$ \\
\hline $\mathrm{PB} 16 \times R s$ & 10.3 & 3.7 & $17.2(24.5)$ & 34.4 (35.9) \\
\hline $\mathrm{PB} 17 \mathrm{x} R s$ & 24.3 & 3.0 & $18.9(25.8)$ & $30.0(33.2)$ \\
\hline $\mathrm{PB} 18 \times R S$ & 13.0 & 4.7 & $16.5(23.9)$ & $34.0(35.7)$ \\
\hline $\mathrm{PB} 19 \mathrm{x} R s$ & 17.3 & 3.3 & $23.8(29.2)$ & $10.0(18.3)$ \\
\hline $\mathrm{PB} 20 \mathrm{x} R s$ & 7.0 & 2.7 & $25.6(30.4)$ & $25.9(30.6)$ \\
\hline $\mathrm{PB} 21 \mathrm{x} R s$ & 11.7 & 3.0 & $14.3(22.2)$ & $46.6(43.0)$ \\
\hline $\mathrm{PB} 22 \mathrm{x} R s$ & 7.7 & 5.7 & $13.6(21.6)$ & $50.4(45.2)$ \\
\hline $\mathrm{PB} 23 \times R s$ & 15.7 & 4.7 & $16.5(24.0)$ & $37.1(37.5)$ \\
\hline $\mathrm{PB} 24 \mathrm{x} R s$ & 6.3 & 2.7 & $22.2(28.1)$ & $22.4(28.2)$ \\
\hline $\mathrm{PB} 25 \mathrm{x} R s$ & 13.3 & 5.7 & $26.6(31.0)$ & $6.0(13.8)$ \\
\hline $\mathrm{PB} 26 \mathrm{x} R s$ & 22.0 & 5.7 & $20.5(26.9)$ & $21.7(27.8)$ \\
\hline $\mathrm{PB} 27 \mathrm{x} R s$ & 10.7 & 2.7 & $21.8(27.9)$ & $26.2(30.7)$ \\
\hline $\mathrm{PB} 28 \mathrm{x} R s$ & 14.3 & 2.0 & $27.1(31.4)$ & $18.3(25.3)$ \\
\hline PB29x $R s$ & 10.0 & 2.7 & $21.9(27.9)$ & $22.5(28.3)$ \\
\hline $\mathrm{PB} 30 \mathrm{x} R s$ & 7.3 & 1.7 & $25.0(30.0)$ & $23.8(29.2)$ \\
\hline $\operatorname{Control}(R s)$ & 31.3 & 5.7 & $34.2(35.8)$ & - \\
\hline $\mathrm{CD}(\mathrm{p}=0.05)$ & 1.19 & 0.73 & 0.48 & 3.81 \\
\hline
\end{tabular}

* Values in bracket are the angular transform values

blight development 30 days after application as seed treatment. More than 50 percent disease suppression was observed only with PB 22 (50.4\%) which was the highest among all the screened isolates. Among the all treatments PB 18 and 23; PB 14, 27 and 29; PB 24, 27 and 29; PB 5 and 30; PB 5, 10 and 20; PB 10, 13 and 20; PB 11 and 25; PB 11 and 28; PB 6 and 28 were at par. Results revealed that $42.5 \%-50.4 \%$ reduction in disease was recorded only with 3 isolates PB 22, PB 21 and PB 3 out of 30 isolates. In all the Trichoderma treatments, total phenolic content in rice leaves was found significantly higher as compare to untreated healthy control before pathogen inoculation (figure 2) which was also higher as compare to those treatments recorded 168 HAPI (figure 2). Maximum phenol content $(468 \mu \mathrm{l} / \mathrm{g})$ was recorded with isolate PB 22 followed by PB 21(456 $\mu \mathrm{l} / \mathrm{g})$ and PB $3(449 \mu \mathrm{l} / \mathrm{g})$ which was significantly higher as compare to untreated healthy control $(201.33 \mu \mathrm{l} / \mathrm{g})$. Significantly higher total phenolic content of rice leaves was also observed 168 hours after pathogen inoculation over untreated pathogen inoculated control (control R.s.). Maximum mean total phenolic content $(394 \mu \mathrm{l} / \mathrm{g})$ in rice leaves was observed with PB 22 as compare to untreated pathogen inoculated control $(216 \mu \mathrm{l} / \mathrm{g})$, which is followed by PB 
$21(389 \mu \mathrm{l} / \mathrm{g})$ and $\mathrm{PB} 3(380.67 \mu \mathrm{l} / \mathrm{g})$.

\section{DISCUSSION}

The isolates PB 2, 3 and 22 were found most effective and gave more $50 \%$ inhibition of hyphal growth of $R$. solani in dual culture were also suppressed the sheath blight disease by more than $34 \%$ when the paddy seeds were treated with dry formulation of these isolates before sowing (Figure 1). Isolate PB 2 that gave maximum per cent inhibition (58.9\%) however it was not found the best isolate to induce the systemic resistance against sheath blight fungus. Li et al. (2001) also studied antagonistic effect of Trichoderma spp. against Rhizoctonia solani. According to Punja and Utkhede (2003) Trichoderma spp. are the most widely studied mycoparasitic fungi. A lot of work has been done with Trichoderma sp. (Elad, 2000, Howell, 2003, Benitez, et al., 2004, Kotasthane et al., 2015) which improved our understanding about mycoparasitism. A similar study was conducted by de-França et al. (2015) a mixture of four isolates of $T$. asperellum was found efficient in reducing the severity of sheath blight and increasing the rice yield and grain weight in Brazil. In addition to the well-recognized mycoparasitic nature of Trichoderma, induction of resistance against pathogens in plants has also been reported by several workers (Benitez et al., 2004, Harman et al., 2004 and Shoresh, et al., 2005) as indirect mechanism of biocontrol. Saksirirat et al. (2009) reported that isolate of T. harzianum (T9) induced resistance in tomato plant (cv. Sida cultivar) with reducing $69.32 \%$ bacterial spot (Xanthomonas campestris pv. vesicatoria) after 14 days post inoculation. Accumulation of increased level of phenols in plants under pathogen challenge or application of bioagent is the first stage of defense mechanism which slows the growth of the pathogen (Kumawat et al., 2008, Gangwar and Sinha, 2014, Vinale et al., 2014). One important observation was recorded with isolate $\mathrm{PB} 9$ that gave more than $50 \%$ inhibition of hyphal growth of $R$. solani in dual culture but found least effective against sheath blight with minimum $(5.9 \%)$ reduction in disease which was also supported with least phenolic content $(286.67 \mu \mathrm{l} / \mathrm{g})$ in paddy leaf 168 HAPI. However, isolate PB 22 identified most potential isolate for the disease suppression ability which was evidenced with highest TPC (394 $\mu \mathrm{l} /$ g) under pathogen challenge (Fig. 2). Sivakumar and Sharma (2003) recorded an increase in phenolic content in maize leaf sheaths inoculated with $R$. solani or plants raised from $P$. fluorescens treated seeds. Karthikeyan et al. (2006) also reported induction of phenolics in coconut roots treated with biocontrol agents (Pseudomonas fluorescens, Trichoderma viride and $T$. harzianum) against Ganoderma disease and they reported maximum level of phenolics after 9 days of treatment application.

\section{Conclusion}

Isolate PB 22 was identified highly efficient to suppress the disease $(50.4 \%)$ and induced resistance in rice against sheath blight pathogen which is evidenced by highest phenolic content $(394 \mu \mathrm{l} / \mathrm{g})$ in leaves of diseased rice plants 168 HAPI. Hence, PB 22 can be utilized under field condition as an alternative of chemical fungicide. In our study, we can also conclude that it is not essential that a good antagonist must be good inducer of systemic resistance as isolate PB 2 was best antagonist against $R$. solani in confrontation assay but weakest to suppress the disease under glass house.

\section{REFERENCES}

Benitez, T., Rincón, A.M., Limón, M.C. and Codón A.C. (2004). Biocontrol mechanisms of Trichoderma strains, Int. Microbiol. 7: 249-260

de França, S.K.S., Cardoso, A.F., Lustosa, D.C., Ramos E.M.L.S., de Filippi M.C.C. and de Silva G.B. (2015). Agron. Sustain. Dev., 35: 317

Dennis, C. and Webster, J. (1971). Antagonistic properties of species group of Trichoderma. I. Production of non volatile antibiotics. Trans. Brit. Mycol., 57: 25-39

Elad, Y. (2000). Biological control of foliar pathogens by means of Trichoderma harzianum and potential modes of action, Crop Prot. 19: 709-714

Gangwar, G.P. and Sinha, A.P. (2014). Effect of fungal and bacterial bioagent application on total phenolic content in rice leaves pre-inoculated with Xanthomonas oryzae pv. oryzae (Uyeda and Ishiyama) Dowson. J. Appl. \& Nat. Sci., 6(1): 254-257

Hanson, L.E. (2000). Reduction of verticillium wilt symptoms in cotton following seed treatment with Trichoderma virens. Journal of cotton science, 4: 224-231

Harman, G.E. (2006). Overview of mechanisms and uses of Trichoderma spp. Phytopathology, 96: 190-194

Harman, G.E., Howell, C.R., Viterbo, A., Chet, I. and Lorito, M. (2004). Trichoderma species-opportunistic, avirulent plant symbionts, Nat. Rev. Microbiol., 2: 43-56

Howell, C.R. (2003). Mechanisms employed by Trichoderma species in the biological control of plant diseases: the history and evolution of current concepts. Plant Disease, 87: 4-10

Karthikeyan, M., Radhika K., Mathiyazhagan S., Bhaskaran R., Samiyappan R. and Velazhahan R. (2006). Induction of phenolics and defense-related enzymes in coconut (Cocos nucifera L.) roots treated with biocontrol agents. Braz. J. Plant Physiol, 18(3): 367-377

Kotasthane, A., Agrawal, T., Kushwah, R. and Rahatkar, O. (2015). In-vitro antagonism of Trichoderma spp. against Sclerotium rolfsii and Rhizoctonia solani and their response towards growth of cucumber, bottle gourd and bitter gourd. European Journal of Plant Pathology, 141 (3): 523-543

Kumawat, G.L., Biswas, S.K. and Srivastava, S.S.L. (2008). Biochemical evidence of defense response in paddy induced by bio-agents against brown leaf spot pathogen. Indian Phytopath., 61 (2): 197-203

Li, M.Y., G.J. Wang, T.F. Li and K. Liu (2001). Selection for Trichoderma isolates applicable in biocontrol of major fungal diseases of tobacco. J. Southwest Agric. Univ., 
23: $10-12$

Pal, R., Biswas, M.K., Mandal, D. and Naik, B.S. (2015). Management of sheath blight disease of rice through bio control agents in west central table land zone of Odisha. International Journal of Advanced Research, 3(11): 747 $-753$

Punja, Z.K. and Utkhede, R.S. (2003). Using fungi and yeasts to manage vegetable crop diseases. Trends Biotechnol., 21: 400-407

Sadasivam, S. and Manickam, A. (1997). Biochemical methods. $2^{\text {nd }}$ edn. New age international (p) Ltd. Publisher, New Delhi, 5 - 207

Saksirirat, W., Chareerak, P. and Bunyatrachata, W. (2009). Induced systemic resistance of biocontrol fungus, Trichoderma spp. against bacterial and gray leaf spot in tomatoes. Asian J. Food Agro-Industry, 2: S99-S104

Segarra, G., van der Ent, S., Trillas, I. and Pieterse, C.M.J. (2009) MYB72, a node of convergence in induced systemic resistance triggered by a fungal and a bacterial beneficial microbe. Plant Biol., 11: 90-96

Sen, B. (2000). Biological control: A success story. Indian Phytopathol., 53: 243-249

Shoresh, M., Yedidia, I.and Chet, I. (2005). Involvement of jasmonic acid/ethylene signaling pathway in the systemic resistance induced in cucumber by Trichoderma asperellum T203, Phytopathology, 95: 76-84

Singh, A., Rohilla, R., Singh,U.S., Savary, S., Willocquet, L. and Duveiller, E. (2000). An improved inoculation technique for sheath blight of paddy caused by $R h i$ zoctonia solani Can. J. Plant Pathol., 24: 65-68

Sivakumar, G. and R.C. Sharma, (2003). Induced biochemical changes due to seed bacterization by Pseudomonas fluorescens in maize plants. Indian Phytopathol., 56: 134-137

Van Wees, S.C.M., van der Ent, S., and Pieterse, C.M.J. (2008). Plant immune responses triggered by beneficial microbes. Curr. Opin. Plant. Biol., 11: 443-448

Vinale, F., Sivasithamparam, K., Ghisalberti, E.L., Woo, S.L., Nigro, M., Marra, R., Lombardi, N., Pascale, A., Ruocco, M., Lanzuise, S., Manganiello, G. and Lorito, M. (2014). Trichoderma secondary metabolites active on plants and fungal pathogens. Mycol. J., 8: 127-139

Yedidia, I., Benhamou, N. and Chet, I. (1999). Induction of defense responses in cucumber plants (Cucumis sativus L.) by the biocontrol agent Trichoderma harzianum. Appl. Environ. Microbiol., 65: 1061-1070 